\title{
Comparison of color indexes for tomato ripening
}

\author{
Andrés F. López Camelo; Perla A. Gómez \\ INTA E.E.A Balcarce, c.c. 276, 7600 Balcarce, Argentina; E-mail: lopezca@balcarce.inta.gov.ar
}

\begin{abstract}
Color in tomato is the most important external characteristic to assess ripeness and postharvest life, and is a major factor in the consumer's purchase decision. Degree of ripening is usually estimated by color charts. Colorimeters, on the other hand, express colors in numerical terms along the $\mathrm{L}^{*}, \mathrm{a}^{*}$ and $\mathrm{b}^{*}$ axes (from white to black, green to red and blue to yellow, respectively) within the CIELAB color sphere which are usually mathematically combined to calculate the color indexes. Color indexes and their relationship to the visual color classification of tomato fruits vine ripened were compared. $\mathrm{L}^{*}, \mathrm{a}^{*}$ and $\mathrm{b}^{*}$ data (175 observations from eleven cultivars) from visually classified fruits at harvest in six ripening stages according to the USDA were used to calculate hue, chroma, color index, color difference with pure red, $\mathrm{a}^{*} / \mathrm{b}^{*}$ and $\left(\mathrm{a}^{*} / \mathrm{b}^{*}\right)^{2}$. ANOVA analysis were performed and means compared by Duncan's MRT. Color changes throughout tomato ripening were the result of significant changes in the values of $\mathrm{L}^{*}, \mathrm{a}^{*}$ and $\mathrm{b}^{*}$. Under the conditions of this study, hue, color index, color difference and $\mathrm{a}^{*} / \mathrm{b}^{*}$ expressed essentially the same, and the color categories were significantly different in terms of human perception, with hue showing higher range of values. Chroma was not a good parameter to express tomato ripeness, but could be used as a good indicator of consumer acceptance when tomatoes are fully ripened. The $\left(\mathrm{a}^{*} / \mathrm{b}^{*}\right)^{2}$ relationship had the same limitations as chroma. For vine ripened fruits, hue, color index, color difference and $\mathrm{a}^{*} / \mathrm{b}^{*}$ could be used as objective ripening indexes. It would be interesting to find out what the best index would be if ripening took place under inadequate conditions of temperature and ilumination.
\end{abstract}

Keywords: Lycopersicon esculentum, postharvest, ripeness, color changes.

\section{RESUMO}

Comparação dos índices de cor para maturação do tomate

A cor do tomate é a característica externa mais importante que permite determinar a maturação e estimar a vida pós-colheita, sendo por sua vez um fator importante na decisão de compra por parte do consumidor. O grau de maturação geralmente é determinado usando cartas de cores. Sem dúvida, com o emprego de colorímetros, podese expressar o grau de maturação em termos de valores nos eixos $\mathrm{L}^{*}, \mathrm{a}^{*}$ e $\mathrm{b}^{*}$ (de branco a preto, verde a vermelho e de azul a amarelo, respectivamente) dentro da esfera de cor CIELAB, que matematicamente combinados, permitem calcular os diferentes índices de cor. O objetivo desse trabalho foi comparar, entre si, os distintos índices de cor e estudar a relação dos mesmos com a classificação visual por cor, para frutos de tomate amadurecidos na planta. Valores de $\mathrm{L}^{*}, \mathrm{a}^{*} \mathrm{e} \mathrm{b}^{*}$ (175 observações provenientes de onze cultivares) correspondentes a frutos que haviam sido previamente classificados em seis estádios de maturação de acordo com a escala USDA, foram empregados para calcular os valores de hue, chroma, índice de cor, diferença de cor com o vermelho puro, relação $a^{*} / b^{*}$ e $\left(a^{*} / b^{*}\right)^{2}$. Os dados foram analisados utilizando-se ANOVA e as médias foram discriminadas pelo teste de Duncan (5\%). A variação de cor durante a maturação provocou variações significativas em $L^{*}, a^{*}$ e b*. Nas condições do presente trabalho, índice de cor, diferença de cor e relação $a^{*} / b^{*}$ tiveram, essencialmente, a mesma expressão, com as categorias de cor significativamente diferentes em termos da percepção humana, entretanto, o valor de hue mostrou uma variação mais ampla de valores. $\mathrm{O}$ chroma não foi um bom parâmetro para expressar os diferentes estádios de maturação, entretanto, seria um bom indicador de aceitação por parte dos consumidores quando os frutos se encontrassem totalmente maduros. A relação $\left(a^{*} / b^{*}\right)^{2}$ apresentou as mesmas limitações que o chroma. Os valores de hue, índice de cor, diferença de cor e relaç!ao $\mathrm{a}^{*} / \mathrm{b}^{*}$ podem ser utilizados indistintamente como índices quando os frutos amadurecem na planta. Sem dúvida, seria interessante determinar-se qual é o melhor índice quando a maturação ocorre sob condições inadequadas de temperatura e iluminação.

Palavras-chave: Lycopersicon esculentum, pós-colheita, maturação, mudanças de cor.

\section{(Recebido para publicação em 24 de junho de 2003 e aceito em 25 de março de 2004)}

$\mathrm{T}$ omatoes are usually consumed at their maximum organoleptic quality which takes place when they reach the full red color stage but before excessive softening. This means that color in tomato is the most important external characteristic to assess ripeness and postharvest life and is a major factor in the consumer's purchase decision. Red color is the result of chlorophyll degradation as well as synthesis of lycopene and other carotenoids, as chloroplasts are converted into chromoplasts (Fraser et al., 1994). Based on the external color, the USDA establishes six ripening stages reflecting human ability to differentiate ripeness: green, $100 \%$ green; breaker, a noticeable break in color with lesser than $10 \%$ of other than green color; turning, between 10 and $30 \%$ of surface, in the aggregate, of red(ish) color; pink, between 30 and $60 \%$ of red(ish) color; light red, between 60 and $90 \%$ and red, more than $90 \%$ red (The California Tomato Board, 1975). Some European countries have established 10 or even more different color stages, but an average consumer has trouble in finding differences between them.

Human identification of colors is quite complex where sensations like brightness, intensity, lightness, vividness and others modify the perception of the primary colors (red, blue, yellow) and their combinations (orange, green, purple, etc.), meaning that in many cases color definition is a matter of subjective interpretation. Although some color 
charts were available by the end of the $18^{\text {th }}$ century, the introduction of the NORM color system in 1931 by the CIE (Commission Internationale de l'Eclairage) made it possible to express color in exact quantitative and numerical terms. An improvement of this system was developed in 1976 (CIELAB color space system), which defines color better related to human perception and where all conceivable colors can be located within the color sphere defined by three perpendicular axes, $\mathrm{L}^{*}$ (from white to black), a* (green to red) and $b^{*}$ (blue to yellow) (Figure 1) (Heilderberg CPS, 1999)

The USDA color classification is widely used for tomato fruits. However, when more precise color description is needed, colorimeters are used measuring $L^{*}, a^{*}$ and $b^{*}$ values. Shewfelt (1993) stated that humans and colorimeters measure color in a different way: humans see colors in terms of lightness, hue and chroma ${ }^{1}$ by integrating complex perceptions. Hue differences are much more easily detected than variations in chroma or lightness. Instruments, on the other hand, are capable of seeing pure values of any $\mathrm{L}^{*}, \mathrm{a}^{*}$ and $\mathrm{b}^{*}$ in the absence of the others.

A given color is fully defined when the achromatic component $\mathrm{L}^{*}$ (relative darkness or lightness) is measured in addition to the chromatic descriptors ( $\mathrm{a}^{*}$ and $\mathrm{b}^{*}$ values) (Pérez-Alvarez et al., 1999; Heildelberg CPS, 1999). However, most of the tomato literature mainly express color changes in terms of different mathematical combinations of $\mathrm{b}^{*}$ and $\mathrm{a}^{*}$ on the chromatic equatorial plane. Some researchers, for example, have only used a* values (Goodenough et al., 1982; Cantwell, 1998), while many others (Babbitt et al., 1973; Gormley \& Egan, 1978, Yang \& Chinnan, 1987; McDonald et al., 1999) have used the a*/ $\mathrm{b}^{*}$ relationship. This ratio has been also utilized to develop mathematical models in order to express color changes at different or constant temperatures (Thorne \& Segurajauregui Alvarez, 1982;
Tijskens \& Evelo, 1994). D'Souza et al. (1992) found a better correlation for lycopene content with $\left(\mathrm{a}^{*} / \mathrm{b}^{*}\right)^{2}$ than any other chromatic index. Hue angle [ $\tan ^{-1}$ $\left.\left(b^{*} / a^{*}\right)\right]$ is another parameter that has been widely used to express tomato color changes (Shewfelt et al., 1987; Thai et al., 1990; Choi et al., 1995).

Very few attempts have been made to incorporate $\mathrm{L}^{*}$ into color models. Shewfelt et al. (1987) used projected lines on the $\mathrm{a}^{*} \mathrm{~b}^{*}$ plane in three-dimensional plots, while Thai et al. (1990) proposed the hue, chroma and L* submodels. Yeatman et al. (1960) developed a raw tomato juice color index later found applicable to whole tomato fruit (Hobson et al., 1983; Dodds et al., 1991) and adapted to the CIEL*a*b* system by López Camelo et al. (1995) and López Camelo \& Gómez (1998). Mathematically, the CIEL*a*b* space could be considered as an euclidean space, where the distance between two points is calculated as the square root of the sum of the squared differences between components (Pérez-Alvarez et al., 1999). If one point is a reference color, i.e. true red or green in the equatorial plane (coordinates: $\mathrm{L}^{*}=50, \mathrm{a}^{*}=+60, \mathrm{~b}^{*}=0$; $\mathrm{L}^{*}=50, \mathrm{a}^{*}=-60, \mathrm{~b}^{*}=0$, respectively), the euclidean distance from any color locus related to the true color could be calculated. The advantage of this method is that all color parameters are included and fully independent from each other. This color difference was used by Yang $e t$ al. (1990) in tomato and by Reyes et al. (1995) who developed a "whiteness index" to express the amount of whitening of minimally processed carrots. In this case, coordinates of pure white $\left(\mathrm{L}^{*}=100\right.$, $a^{*}=0, b^{*}=0$ ) were used.

Which is the best color index to express color changes in tomato is a question that remains to be answered, defining as best that which is closer to human perception, taking into account that the average consumer has trouble to differentiate more than six ripening stages. Then, the objective of this research was to compare all color indexes used in the literature in relationship to the visual color classification based in the USDA system.

\section{MATERIAL AND METHODS}

This study analyzed colorimeter readings (175 observations from eleven cultivars) collected in five years where tomatoes were classified at harvest according to color requirements of the USDA standards (six stages). $\mathrm{L}^{*}, \mathrm{a}^{*}$ and $b^{*}$ values were measured with a Minolta chroma meter (CR-300 with an 8-mm aperture) and each record was an average of four measurements on every tomato fruit (one at the distal area and three in the equatorial zone). Colorimeter was calibrated against a standard white tile $\left(\mathrm{L}^{*}=96.82 ; \mathrm{a}^{*}=-0.02 ; \mathrm{b}^{*}=2.04\right.$, illuminant condition $\mathrm{C}, 6774 \mathrm{~K}$ ).

The different color indexes were calculated according to the following equations: hue: $\tan ^{-1}\left(\mathrm{~b}^{*} / \mathrm{a}^{*}\right)^{2}$; chroma: $\left(\mathrm{a}^{* 2}+\mathrm{b}^{* 2}\right)^{0.5}$; color index: $2000 x \mathrm{a}^{*} / \mathrm{L} *$ $x\left(\mathrm{a}^{* 2}+\mathrm{b}^{* 2}\right)^{0.5}$ (López Camelo et al., 1995), color difference with true red (DE): $\left[(\mathrm{L} *-50)^{2}+\left(\mathrm{a}^{*}-60\right)^{2}+\mathrm{b}^{* 2}\right]^{0.5}, \mathrm{a}^{* /}$ $\mathrm{b}^{*}$ and $\left(\mathrm{a} * / \mathrm{b}^{*}\right)^{2}$. Data were plotted and ANOVA analysis was performed. Means were compared by multiple range tests (Duncan, 5\%).

\section{RESULTS AND DISCUSSION}

The a* component showed the most obvious change, following a typical sigmoid trend (Figure 2). No major changes were observed when fruits were still predominately green (mature green to breaker) or red (light red to red), but there was a sharp increase between stages 2 and 5 (breaker to light red) with $\mathrm{a} *$ changing from negative (green color) to positive (red color) values, as a consequence of both, chlorophyll degradation and lycopene synthesis. L* values did not change until the turning stage, indicating that there was not change in lightness when the green color was still predominant. When red color pigments started to be synthesized, a decreasing $L^{*}$ value indicated the

\footnotetext{
${ }^{1}$ Hue or true color is the angle between the color vector and the a+ axis, chroma (purity or saturation) is the distance between the color locus and the mid-point. Both on the equatorial plane $\left(a^{*}-b^{*}\right)$ of the color sphere.

By definition chroma $=0$ for white and black colors.

${ }^{2}$ When $\mathrm{a}^{*}<0, \mathrm{H}^{\circ}=180+\tan -1\left(\mathrm{~b}^{*} / \mathrm{a}^{*}\right)$
} 


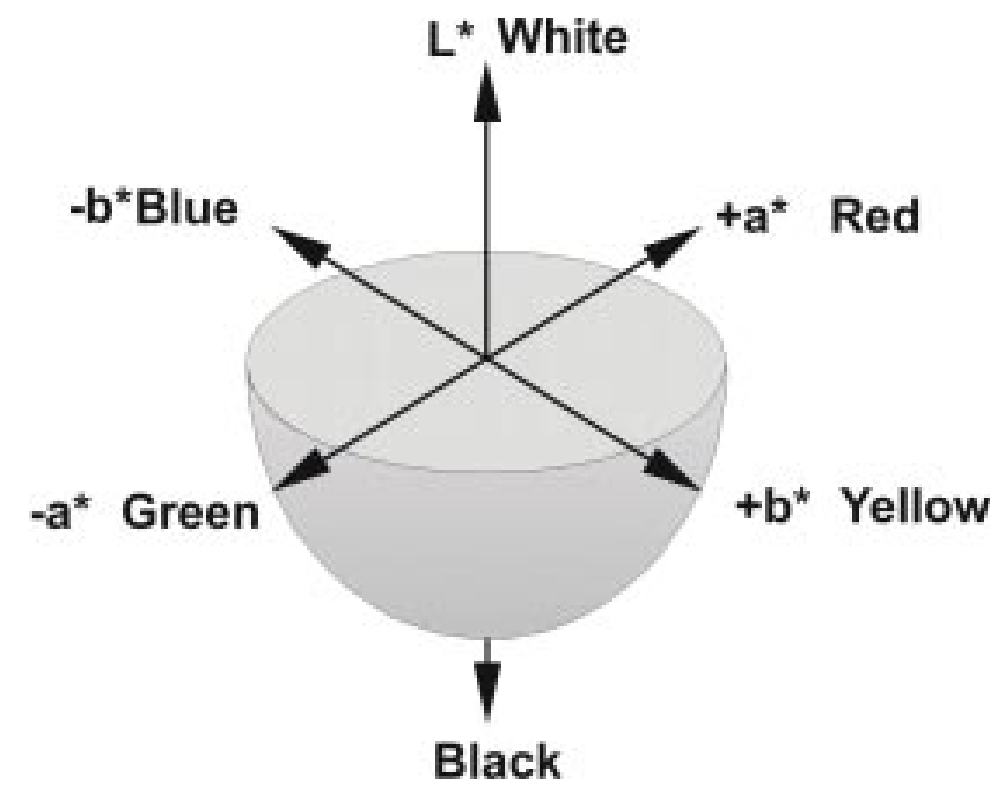

Figure 1. The CIELAB color space system. Balcarce, Argentina. INTAE.E.A. Balcarce, 2001.

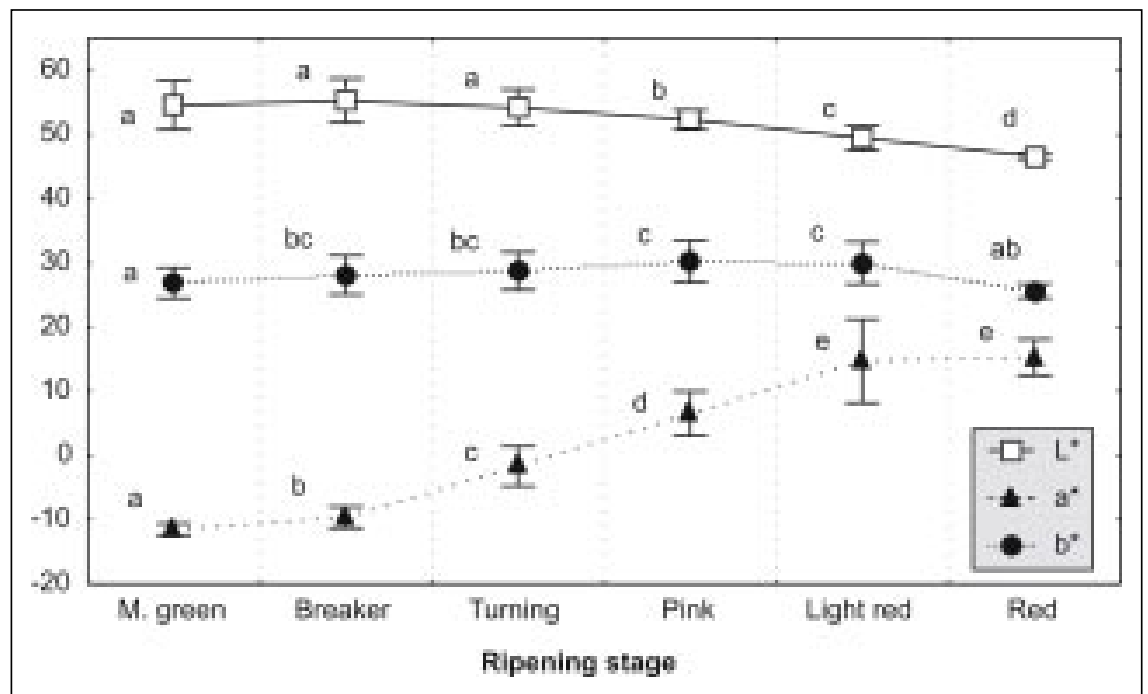

Figure 2. $\mathrm{L}^{*}, \mathrm{a}^{*}$ and $\mathrm{b}^{*}$ mean values at different ripening stages of tomato fruits.

(Values with the same letter within each color parameter are not different, Duncan, 5\%). Balcarce, Argentina. INTA E.E.A. Balcarce, 2001.

darkening of the red color (from pink to full red). As some researchers showed previously (López Camelo et al., 1995; López Camelo \& Gómez, 1998; Arias et al., 2000), b* values changed very little during ripening and, although not significant, values were higher at the pink-light red stage. This may be related to the fact that $\zeta$-carotenes (pale-yellow color) reach their highest concentration before full ripening, where lycopene (red color) and $\beta$-carotene (orange color) achieve their peaks (Fraser et al., 1994; Choi et al., 1995).
Analysis of calculated ripening indexes indicated that hue, color index, color difference and $\mathrm{a} * / \mathrm{b} *$ were essentially expressing the same (Table 1). In all these cases, differences between visual ripening stages were significant, showing hue a higher range of values and, like color difference, a negative trend. Color index and $\mathrm{a}^{*} / \mathrm{b}^{*}$ increased with higher percentage of red color. Our data indicated that those mathematical relationships among color parameters may be applicable at least for fruits ripening on the vine, where changes along the greenred axis $\left(a^{*}\right)$ are so big that mask any other change in the other two parameters.

Chroma did not change in the earlier ripening stages for a later increase as the tomatoes changed from pink to light red to finally decline at the red stage (Table 1). Although a chroma submodel has been proposed (Thai et al., 1990), it is not a good indicator of tomato ripening because it essentially is an expression of the purity or saturation of a single color (different colors may have the same chroma values). In the case of tomato ripening, different colors are present simultaneously since chlorophyll is degraded from green to colorless compounds at the same time that carotenoids are synthesized from colorless precursor (phytoene) to $\xi$-carotene (paleyellow), lycopene (red), $\beta$-carotene (orange) and xanthophylls and hydroxylated carotenoids (yellow) (Giuliano et al., 1993), in a kind of parallel biosynthetic pathway (Horton \& Stark, 1969). Additionally, as chroma is calculated by squaring $\mathrm{a}^{*}$ and $\mathrm{b}^{*}$ values it makes positive the negative $a^{*}$ values (green color) masking its influence. Lastly, the lower values tend to be those where $\mathrm{a}^{*}$ readings are close to 0 (turning stage, Figure 2). Because chroma reflects color purity or saturation, it could be a good indicator of consumer acceptance when tomatoes are completely ripe. Calculations based on $\mathrm{a}^{*}$ and $\mathrm{b}^{*}$ values obtained from a comparison of consumer preference between orange and different intensity of red cultivars (Gorini \& Testoni, 1990), indicated that chroma is more related to consumer acceptance than hue, indicating their preference for more red cultivars. Finally, due to the fact that squaring makes positive the negative values, the mathematical relationship $\left(a^{*} / b^{*}\right)^{2}$ also failed to detect differences between the turning and pink color stages (Table 1).

In postharvest studies, however, constant or abnormal light and temperature conditions may influence $\mathrm{L}^{*}, \mathrm{a}^{*}$ and $\mathrm{b}^{*}$ values and the ripening index to be used should be carefully selected. Although Horton \& Stark (1969) did not find differences in carotenoid synthesis between light exposed and shaded fruits, Shewfelt $e t$ al. (1987) indicated that the screening out of light inhibited $\beta$-carotene 
synthesis. In the same way, Thomas \& Jen (1975) found that exposure to light could lead to increased accumulation of $\beta$-carotene.

Color development in tomatoes is temperature sensitive with better plastid conversion occurring above $12^{\circ} \mathrm{C}$ and below $30^{\circ} \mathrm{C}$ (Thai et al., 1990). Tijskens \& Evelo (1994) demonstrated that $b^{*}$ suffered big changes if tomatoes were ripened at high temperatures (over $30^{\circ} \mathrm{C}$ ) and yellowing took place due to the inhibition of lycopene synthesis and the accumulation of yellow/orange carotenoids. On the other hand, at low temperatures (below $12^{\circ} \mathrm{C}$ ), chlorophyll is not degraded and lycopene accumulation does not take place. This may indicate that under other than normal ripening conditions, changes in the $b^{*}$ values may compensate or exaggerate $\mathrm{a}^{*}$ magnitudes, depending on their mathematical relationship, leading to misleading results. This indicates that under abnormal ripening conditions, $\mathrm{b}^{*}$ and $\mathrm{L}^{*}$ changes may be important and the ripening index to be used should be carefully selected.

Color changes during tomato ripening were the result of changes in the values of $L^{*}, a^{*}$ and $b^{*}$, although the more important ones were along the $a^{*}$ axis, related to chlorophyll degradation and lycopene synthesis. Accurate color identification among the six ripening stages based on USDA visual classification should include the three parameters. In vine ripening conditions hue, color index, color difference and $\mathrm{a} * \mathrm{~b} *$ relationships could be used as objective ripening indexes giving a realistic estimation of consumer perception, being $a * / b *$ sufficient for practical purposes. The best index should be established, however, when fruits are ripened under limiting temperature or illumination conditions.

\section{CITED LITERATURE}

ARIAS, R.; LEE, T.; LOGENDRA, L.; JANES, H. Correlation of lycopene measured by HPLC with the $\mathrm{L}^{*}, \mathrm{a}^{*}, \mathrm{~b}^{*}$ color readings of a hydroponic tomato and the relationship of maturity with color and lycopene content. Journal of Agricultural Food Chemistry, v.48, p.1697-1702, 2000. BABBIT, J.K.; POWERS, M.J.; PATTERSON, M.E. Effects of growth-regulators on cellulase, polygalacturonase, respiration, color and texture of ripening tomatoes. Journal of the American Society for Horticultural Science, v.98, n.1, p.77-81, 1973.

Table 1. Ripening indexes values for tomato fruits harvested at different color stages. Balcarce, Argentina. INTA E.E.A. Balcarce, 2001.

\begin{tabular}{lcrrrrr}
\hline $\begin{array}{l}\text { Visual } \\
\text { Color }\end{array}$ & Chroma & Hue & $\begin{array}{r}\text { Color } \\
\text { index }\end{array}$ & $\begin{array}{c}\text { Color } \\
\text { difference }\end{array}$ & $\mathbf{a}^{*} / \mathbf{b}^{*}$ & $\left.\mathbf{( a}^{*} / \mathbf{b}^{*}\right)^{\mathbf{2}}$ \\
\hline M. Green & $29.3 \mathrm{a}^{1 /}$ & $113.3 \mathrm{a}$ & $-14.6 \mathrm{a}$ & $76.7 \mathrm{a}$ & $-0.43 \mathrm{a}$ & $0.19 \mathrm{a}$ \\
Breaker & $29.8 \mathrm{a}$ & $109.1 \mathrm{~b}$ & $-11.9 \mathrm{~b}$ & $75.4 \mathrm{~b}$ & $-0.35 \mathrm{~b}$ & $0.12 \mathrm{~b}$ \\
Turning & $28.9 \mathrm{a}$ & $93.2 \mathrm{c}$ & $-2.0 \mathrm{c}$ & $68.2 \mathrm{c}$ & $-0.06 \mathrm{c}$ & $0.02 \mathrm{c}$ \\
Pink & $31.0 \mathrm{a}$ & $78.1 \mathrm{~d}$ & $7.8 \mathrm{~d}$ & $61.6 \mathrm{~d}$ & $0.21 \mathrm{~d}$ & $0.05 \mathrm{c}$ \\
Light Red & $33.7 \mathrm{~b}$ & $64.9 \mathrm{e}$ & $17.1 \mathrm{e}$ & $54.7 \mathrm{e}$ & $0.48 \mathrm{e}$ & $0.26 \mathrm{~d}$ \\
Red & $29.9 \mathrm{ab}$ & $59.3 \mathrm{f}$ & $21.8 \mathrm{f}$ & $51.7 \mathrm{f}$ & $0.59 \mathrm{f}$ & $0.36 \mathrm{e}$ \\
\hline
\end{tabular}

$\overline{1 /}$ Values with the same letter within the same column are not significantly different (Duncan, 5\%).

CANTWELL, M. Optimum procedures for ripening tomatoes. In: KADER, A. (Ed.) Management of fruit ripening, Postharvest Horticulture Series. University of California, Davis, n. 9. Postharvest Outreach Program, 1998. CHOI, K.; LEE, G.; HAN, Y.J.; BUNN, J.M Tomato maturity evaluation using color image analysis. Transactions of the ASAE, v.38, n.1, p.171-176. 1995.

DODDS, G.T.; BROWN, J.W.; LUDFORD, P Surface color changes of tomato and other solanaceous fruit during chilling. Journal of the American Society for Horticultural Science, v.166, n.3, p.482-490, 1991.

D'SOUZA, M.C.; SINGHA, S.; INGLE, M Lycopene concentration of tomato fruit can be estimated from chromaticity values. HortScience, v.27, n.5, p.465-466, 1992.

FRASER, P.D.; TRUESDALE, M.R.; BIRD C.R.; SCHUCH, W.; BRAMLEY, P.M. Carotenoid biosynthesis during tomato fruit development. Plant Physiology, v.105, p.405-413, 1994.

GOODENOUGH, P.W.; TUCKER; G.A.; GRIERSON, D.; THOMAS, T. Changes in color polygalacturonase monosaccharides and organic acids during storage of tomatoes. Phytochemistry, v.21, p.281-284, 1982.

GORINI, F.L.; TESTONI, A. The relation between colour and quality of vegetables. Acta Horticulturae, v.259, p.31-60, 1990.

GORMLEY, R.; EGAN, S. Firmness and colour of the fruit of some tomato cultivars from various sources during storage. Journal of Science Food Agriculture, v.29, p.534-538, 1978.

GIULIANO, G.; BARTLEY, G.E.; SCOLNIK, P.A. Regulation of carotenoid biosynthesis during tomato development. The Plant Cell, v.5, p.379387, 1993.

HEILDELBERG CPS, Americas. Color manager manual. Disponível em: <http:// www.heidelbergcps.com/colorman/ sp_ciela_1.htm $>$. Acesso em 1999.

HOBSON, G.E.; ADAMS, P.; DIXON, T.J. Assessing the colour of tomato fruit during ripening. Journal of Science Food Agricultural, v.34, p.286-292, 1983.

HORTON, B.D.; STARK, F.C. Developmental rates and biosynthesis of carotenoids in tomatoes (Lycopersicon esculentum Mill.) as influenced by two solar radiation levels. Maryland Agricultural Experimental Station Bulletin. 1969. 19 p.

LOPEZ CAMELO, A.F.; GOMEZ, P.A.; CACACE, J.E. Modelo para describir los cambios de color en tomate (cv. Tommy) durante la poscosecha. In: CONGRESO ARGENTINO DE HORTICULTURA, 18, 1995. Termas de Río Hondo, Argentina. Resúmenes, ASAHO, p.212.
LOPEZ CAMELO, A.F.; GOMEZ, P.A. Modeling postharvest color changes in long shelf life tomatoes. In: INTERNATIONAL HORTICULTURAL CONGRESS, 25, 1998. Brussels, Belgium. Abstracts, ISHS, p. 9 supplement.

McDONALD，R.E.; McCOLLUM，T.G.; BALDWIN, E.A. Temperature of water heat treatments influences tomato fruit quality following low-temperature storage. Postharvest Biology and Technology, v.16, p.147-155, 1999. PEREZ-ALVAREZ, J.A.; FERNANDEZLOPEZ, J.; SAYAS, M.E.; ROSMINI, M.R. Determinación objetiva del color en los alimentos. TechnoFOOD, n.11, p.18-28, 1999.

REYES, V.G.; SIMONS, L.; TRAN, C. Preservation of minimally processed carrots by edible coating and acid treatment. In: AUSTRALASIAN POSTHARVEST HORTICULTURE CONFERENCE, p.451-456, 1995.

SHEWFELT, R.L. Measuring quality and maturity. In: SHEWFELT, R.L.; PRUSSIA, S.E. (Eds.) Postharvest handling: a systems approach. New York, Academic Press, p.99-124, 1993.

SHEWFELT, R.L.; PRUSSIA, S.E.; RESURRECCION, A.V.; HURST, W.C.; CAMPBELL, D.T. Quality changes of vineripened tomatoes within the postharvest handling system. Journal of Food Science, v.52, n.3, p.661672, 1987.

THAI, C.N.; SHEWFELT, R.L.; GARNER, J.C. Tomato color changes under constant and variable storage temperatures: empirical models. Transactions of the ASAE, v.33, n.2, p.607-614, 1990.

THE CALIFORNIATOMATO BOARD. Ripening stages for tomatoes. USDA visual aid. 1975.

THOMAS, R.L.; JEN, J.J. Phytochrome-mediated carotenoids bio-synthesis in ripening tomatoes. Plant Physiology, v.56, p.452-453, 1975.

THORNE, S.; SEGURAJAUREGUI-ALVAREZ, J.S. The effect of irregular storage temperatures on firmness and surface colour in tomatoes. Journal of Science Food Agricultural, v.33, p.671676, 1982.

TIJSKENS, L.M.; EVELO, R.G. Modeling colour of tomatoes during postharvest storage. Postharvest Biology and Technology, v.4, p.85-98, 1994.

YANG, C.; CHINAN, M. Modeling of color development of tomatoes in modified atmosphere storage. Transactions of the ASAE, v.30, n.2, p.548-543, 1987.

YANG, R.F.; CHENG, T.S.; SHEWFELT, R.L.. The effect of high temperature and ethylene treatment on the ripening of tomatoes. Journal of Plant Physiology, v.136, p.368-372, 1990

YEATMAN, J.N.; SIDWELL, A.P.; NORRIS, K.H. Derivation of a new formula for computing raw juice color from objective color measurements. Food Technology, v.14, p.16-20, 1960. 